\title{
Local Officials' Change and Corporate Investment-Evidence from Listed Companies in Strategic Emerging Industries
}

\author{
Jiang Zhu \\ School of Economics, Jinan University, Guangzhou, China \\ Email: zjjjx1924@163.com
}

How to cite this paper: Zhu, J. (2017) Local Officials' Change and Corporate Investment-Evidence from Listed Companies in Strategic Emerging Industries. Open Journal of Business and Management, 5, 290-297.

https://doi.org/10.4236/ojbm.2017.52026

Received: February 27, 2017

Accepted: April 22, 2017

Published: April 25, 2017

Copyright $\odot 2017$ by author and Scientific Research Publishing Inc. This work is licensed under the Creative Commons Attribution International License (CC BY 4.0).

http://creativecommons.org/licenses/by/4.0/

\begin{abstract}
Based on the sample of listed companies in strategic emerging industries between 2007 and 2014 of China Shanghai and Shenzhen Stock Market, this paper tested the effect of the change of the local prefecture level city mayor and party secretary on corporate investment, and further studies differentiated different enterprise types. The results indicated that the change of prefecture level city party secretary will lead to the significant increase of strategic emerging industries listed companies investment and this effect occurs only in the second year; we have not found significant effect of the change of the local prefecture level city mayor. Further, this paper limited examples. We found that the investment of state-owned enterprises were influenced significantly by the change of prefecture level city party secretary and this effect lagged one phase, major's turnover had no significant effect. Higher market degree companies and higher government subsidies companies showed similar results. The result of his paper has enriched the study of the relationship between local officials' change and corporate investment.
\end{abstract}

\section{Keywords}

Local Officials' Change, Corporate Investment, Strategic Emerging Industries

\section{Introduction}

The State Council issued "Decision on accelerating the cultivation and development of strategic emerging industry" on October 8, 2010, which clearly pointed out that the strategic emerging industry is an important force in China's economic and social development in the future. Later, the State Council and local governments introduced a series of related policies for the development of strategic emerging industries, including the establishment of various types of finan- 
cial special support funds, planning and construction of strategic emerging board and giving preferential tax policies. As of the first half of 2015, the listed companies of strategic emerging industry nearly are 900, accounting for about $32 \%$ of the total number of listed companies; at the same time, the overall quality of strategic emerging industries is relatively higher, and it's revenue growth rate and profitability is much larger than the overall listed companies. Strategic emerging industries in the short term achieve such a huge development, which is closely related with government supports.

In China, because of special political system arrangement, the local governments autonomously have the right to make economic decisions and share the revenue with the central government, thus under certain promotion mechanism encouraging local officials to maintain the market, promote local economic growth, so local officials play an important role in China's local economic growth $(\mathrm{Xu}, 2011)$ [1]. At the same time, the officials are different, which leads to different effects on economic growth, then as an important aspect of the change of official characteristics, the change of officials will also affect the local economic growth. Based on the above understanding, the existing researches contain two aspects: Macroeconomic and micro-enterprise perspective, which analyze the main impact of the official changes on economic behavior. Although not completely significant, the conclusion also shows that changes in local officials do have a certain impact on various types of economic behavior. .As an important part of the local economy, the economic behaviors of strategic emerging industry listed companies are also inevitable to be affected by the changes of government officials

In China, the official change is normal. There are many factors that lead to the change of officials, such as the exchange of officials, the retirement age, the general election and some special reasons. So, what will be the impact of the region's strategic emerging industries listed companies spending on investment? similar analysis contain, Cao Chunfang (2013), Xu Yekun (2013), Jia Qian (2013) and Chen Yanyan (2012) studies using different sample data to analyze the effect of the local officials' change on firm's investment. Thus, the strategic emerging industries as a special category of listed companies, whether local officials' change will affect their investment behavior? If so, what are the characteristics of this effect?

Based on the above analysis, this paper uses strategic emerging industries listed company data from 2007 to 2014, analyzing the influence of the prefecture level city mayor, Party Secretary of the change occurred in the industry of listed companies investment spending. The conclusion shows that the change of prefecture level city party secretary will lead to the significant increase of strategic emerging industries listed companies investment and this effect occurs only in the second year, we have not found significant effect of the change of the local prefecture level city mayor. This paper is similar with Chen Yanyan and Luo (2012), but there are at least three points different from this paper: first, this paper use strategic emerging industries listed company data from 2007 to 2014, 
while the sample of Chen and Luo based on industrial enterprises between 1999 and 2009;second,this paper collected the data of major and party secretary, and the result shows that the change of party secretary will affect companies' investment only, but Chen and Luo's result shows that major' turnover have a significant influence; third, this paper differentiated different enterprise types. Therefore, the empirical analysis in this paperenriches the existing literature.

The rest of this paper are organized as follows: Section 2 is the literature review; Section 3 is the research design of concrete; Section 4 is descriptive statistics and empirical results to illustrate the robustness test; Section 5 makes a conclusion.

\section{Literature Review}

There are many literatures on the relationship between government and economic growth from a macroeconomic perspective, such as Johnson (1982), Amsden (1989), Wade (1990), Frye and Shelifer (1993), World Bank (1993), Qian and Weingast (1997) [2] [3] [4] [5] [6].

All of them regard the government as a whole, without paying attention to the behavior of individual officials'. But since the 21st century, the study of individual government officials has gradually increased. Such as Jones and Olken (2005) [7], Zhou Li'an (2004, 2007), Li and Zhou (2005), Xu Xianxiang et al. (2007), Wang Xianbin et al. (2009), and Luo's theory and She Min guo (2015), which analyzed the impact of government officials on economic growth from different perspectives.

Micro-enterprise level analysis has also been concerned about. Bernanke's (1983) study shows that when firms face political uncertainty, their investment behavior becomes cautious, either reducing investment, or delaying investment until political uncertainty is eliminated [8]. Bloom et al. (2008) found that uncertainty does lead to a reduction in economic activity, mainly because firms are becoming more cautious in job hiring and investment decisions, while uncertainty also reduces the redistribution of capital and labor, leading to a sharp decline in labor productivity [9]. Julio and Yook (2012) used cross-country data showing that corporate investment spending during the electoral period will be significantly reduced by 5.3 percentage points [10]. Yonce's (2010) study also found that the average level of investment in US companies declined significantly from 1964 to 2008, with an average reduction of about 2 percentage points [11]. Cohen et al. (2011) concluded that when the Senate and the Chairman of the House Committee changed, the new chairman would lead to an increase in local government spending, which would have a squeeze effect on private sector investment and a significant drop in private sector investment spending [12]. The Pastor and Veronesi (2012) also showed that when the political environment changes, the enterprise investment spending will be reduced relatively [13].

More and more researches focus on China, such as Chen Yanyan and Luo Fang (2012), Cao (2013), Xu (2013), and Jia (2013). all of the above studies have shown that the government and officials' behavior will have a certain impact on 
both macroeconomics and microeconomics. According to the conclusion of this paper, the strategic emerging industries and the government is closely related to the development of strategic emerging industries by the government's strong guidance and support, but the existing literature on the relationship between the government and strategic emerging industries only concerned about the government as a whole, no further literature examines the effect of the individual government officials. Based on these factors, this paper will focus on examining the impact of government officials' changes on investment spending on strategic emerging industry listed companies.

\section{Research Design}

\subsection{Sample Selection}

This paper chooses the data of listed companies of strategic emerging industries from stock markets between 2007 and 2014 as the research samples, which are mainly classified by the Wind database. The samples were selected by the following procedures: 1) removing duplicate samples; 2) excluding listed companies whose status is ST or ${ }^{\star} \mathrm{ST}$; 3 ) excluding the samples listed on stocked markets in 2014; 4) deleting samples of company registration and office inconsistencies. finally, we have 758 samples.

\subsection{Test Model and Variable Description}

According to the above analysis, this paper constructs model (1) and model (2) as follows:

$$
\begin{aligned}
\text { invest }_{i t-1}= & \alpha_{0}+\alpha_{1} \text { shuji }_{i t}+\alpha_{2} \text { gdp }_{i t-1}+\alpha_{3} \text { roa }_{i t}+\alpha_{4} \text { growth }_{i t}+\alpha_{5} \text { assetdebt }_{i t}+\alpha_{6} \text { cash }_{i t} \\
+ & \alpha_{7} \text { managefe }_{i t}+\alpha_{8} \text { occupy }_{i t}+\sum \text { year }+\sum i n d+\varepsilon_{i t} \\
\text { invest }_{i t-1}= & \beta_{0}+\beta_{1} \text { shizhang }_{i t}+\beta_{2} \text { gdp }_{i t-1}+\beta_{3} \text { roa }_{i t}+\beta_{4} \text { growth }_{i t}+\beta_{5} \text { assetdebt }_{i t} \\
& +\beta_{6} \text { cash }_{i t}+\beta_{7} \text { managefee }_{i t}+\beta_{8} \text { occupy }_{i t}+\sum \text { year }+\sum \text { ind }+\varepsilon_{i t}
\end{aligned}
$$

$i$ is the individual and $t$ is the time.

\subsubsection{Variable Description}

Explained variables: we defined the enterprise investment expenditure used by Jia Qian (2013) as invest1, and we used the definition conducted by Cao (2013) as invest 2 , which is used for robustness check. those variables are adjusted by the total assets at the beginning of the year.

Explanatory variables: we denoted party secretary changes as shuji, according to Cao Chunfang (2013) and Dai Yiyi (2014), if party secretary changes before July 1 , we define that year as 1 ; but if party secretary changes after July 1 , we define next year as 1 . If there are two changes in one year, according to Dai Yiyi (2014), we only conduct the second change. We define mayor change ( shizhang ) as the above.

In this paper, we also contain several control variables as Table 1 showed. In addition to the above control variables, this paper controls the time ( year ) and industry (ind ) fixed effects in each model. 


\section{Empirical Results and Analysis}

\subsection{Descriptive Statistics of Data}

The data on the change of officials were selected from City Network, enterprise financial data used by this paper were obtained from Wind database. Then descriptive statistics of data are as in Table 1.

\subsection{Empirical Results and Analysis}

\subsubsection{Changes in Local Government Officials and Corporate Investment}

In order to examine the impact of local government officials on the investment expenditure of Listed Companies in strategic emerging industries within the jurisdiction of the region, this paper carries on the regression models (1)-(2). Table 2 reports the specific regression results.

In Table 2, the change of municipal Party Secretary has a significant positive effect on the investment expenditure, which only happens on next year, but the change of mayor shows no significant effect. This conclusion proves our analysis, which confirms that the municipal Party committee secretary is the power center.

\subsubsection{The Change of Officials and Investment in Different Samples}

Table 3 reports the regression results of different samples. In Table 3, the effect of mayor's change is not significant, so this table only reports the results of the Party Secretary. First of all, column (1) and column (2) show that the change will lead the investment of state-owned enterprises increased significantly next year, but the impact of investment in non state-owned enterprises is not significant. Secondly, column (3) and column (4) show that, in the high degree of market area, the change has significant effect,; but in other areas, this result is insignificant. Finally, in column (5) and column (6), only the investment of the companies received more government subsidies increased significantly next year.

Table 1. Descriptive statistics.

\begin{tabular}{ccccc}
\hline variables & mean & $\begin{array}{c}\text { Standard } \\
\text { deviation }\end{array}$ & max & min \\
\hline shuji & 0.2233321 & 0.4165184 & 1 & 0 \\
shizhang & 0.2436864 & 0.4293461 & 1 & -0.3258109 \\
invest1 & 0.107999 & 0.1207495 & 2.685182 & -0.326216 \\
invest2 & 0.0955205 & 0.1136603 & 2.681915 & -0.2951004 \\
gdp & 0.1357768 & 0.0604612 & 0.6320553 & -1.22991 \\
roa & 0.1298987 & 0.143678 & 1.029236 & 0.0079691 \\
growth & 0.4327682 & 0.2137169 & 1.115697 & 0.0079691 \\
assetdebt & 0.4038459 & 0.2018483 & 0.9636964 & -0.3499927 \\
cash & 0.0547813 & 0.0860451 & 0.7684953 & 0.0006718 \\
managefee & 0.0581087 & 0.0384164 & 0.3719189 & 0 \\
occupy & 0.0153318 & 0.0257191 & 0.702214 & \\
\hline
\end{tabular}


Table 2. Regression results.

\begin{tabular}{|c|c|c|c|c|}
\hline & \multicolumn{2}{|c|}{ lag one phase } & \multicolumn{2}{|c|}{ recent } \\
\hline & Invest 1 & Invest 1 & Invest 1 & Invest 1 \\
\hline \multirow[t]{2}{*}{ shuji } & $0.00828^{\star *}$ & & 0.000321 & \\
\hline & $(0.00344)$ & & $(0.00353)$ & \\
\hline \multirow[t]{2}{*}{ shizhang } & & 0.000698 & & 0.00393 \\
\hline & & $(0.00295)$ & & $(0.00337)$ \\
\hline \multirow[t]{2}{*}{ cash } & $0.0893^{* * *}$ & $0.0898^{\star * *}$ & $0.0898^{* * *}$ & $0.0904^{* * *}$ \\
\hline & $(0.0292)$ & $(0.0291)$ & $(0.0292)$ & $(0.0291)$ \\
\hline \multirow[t]{2}{*}{ assetdebt } & $0.0921^{* *}$ & $0.0916^{* *}$ & $0.0917^{\star *}$ & $0.0917^{\star *}$ \\
\hline & $(0.0455)$ & $(0.0454)$ & $(0.0456)$ & $(0.0453)$ \\
\hline \multirow[t]{2}{*}{ growth } & $-0.0977^{\star *}$ & $-0.0974^{\star *}$ & $-0.0975^{\star *}$ & $-0.0974^{\star *}$ \\
\hline & $(0.0418)$ & $(0.0416)$ & $(0.0418)$ & $(0.0416)$ \\
\hline \multirow[t]{2}{*}{ roa } & $0.00131^{\star * *}$ & $0.00130^{* * *}$ & $0.00130^{* * *}$ & $0.00130^{* * *}$ \\
\hline & $(0.000187)$ & $(0.000187)$ & $(0.000187)$ & $(0.000187)$ \\
\hline \multirow[t]{2}{*}{ occupy } & $-0.345^{\star * *}$ & $-0.347^{\star * *}$ & $-0.347^{* * *}$ & $-0.348^{\star * *}$ \\
\hline & $(0.0864)$ & $(0.0863)$ & $(0.0863)$ & $(0.0863)$ \\
\hline \multirow[t]{2}{*}{ managefee } & $-0.430^{* * *}$ & $-0.430^{* * *}$ & $-0.430^{* * *}$ & $-0.431^{\star * *}$ \\
\hline & $(0.0908)$ & $(0.0907)$ & $(0.0907)$ & $(0.0907)$ \\
\hline \multirow[t]{2}{*}{$g d p$} & $0.0899^{* *}$ & $0.0888^{\star *}$ & $0.0890^{* *}$ & $0.0893^{\star *}$ \\
\hline & $(0.0421)$ & $(0.0421)$ & $(0.0420)$ & $(0.0421)$ \\
\hline \multirow[t]{2}{*}{ _cons } & $0.124^{\star * *}$ & $0.132^{* * *}$ & $0.133^{* * *}$ & $0.128^{\star * *}$ \\
\hline & $(0.0150)$ & $(0.0147)$ & $(0.0154)$ & $(0.0154)$ \\
\hline year & control & control & control & control \\
\hline ind & control & control & control & control \\
\hline adj. $R^{2}$ & 0.071 & 0.071 & 0.071 & 0.071 \\
\hline$N$ & 5175 & 5175 & 5175 & 5175 \\
\hline
\end{tabular}

The standard deviation of the brackets in the table. ${ }^{\star} \mathrm{P}<0.10,{ }^{* *} \mathrm{P}<0.05,{ }^{* * *} \mathrm{P}<0.01$. The model is adjusted by individual cluster.

\subsection{Robustness Check}

The results of robustness test shown in Table 4. First, we replaced invest 1 with invest 2 , finding that only the change of party secretary will lead the investment of companies significantly increase; second, we use provincial official repeating the above regressions, the results showed that only the change of provincial party committee secretary will lead to significant investment in the next year, a significant increase in investment spending; third, removing the sample of municipality company, the results keep consistent with the above.

\section{Conclusion}

This paper chooses the strategic emerging industry listed companies as the research samples, and analyzes the influence of the change of officials on the investment of the listed companies. Furthermore, this paper analyzes the different 
Table 3. Regression results of different samples.

\begin{tabular}{ccccccc}
\hline \multirow{2}{*}{ shuji } & \multicolumn{2}{c}{ Property right } & \multicolumn{2}{c}{ Marketization degree } & \multicolumn{2}{c}{ Receive government subsidies } \\
\cline { 2 - 7 } & invest 1 & invest 1 & invest 1 & invest 1 & invest 1 & invest 1 \\
\hline \multirow{3}{*}{ cash } & $0.00741^{*}$ & 0.00669 & $0.00837^{* *}$ & 0.00293 & $0.00878^{*}$ & 0.00658 \\
& $(0.00433)$ & $(0.00561)$ & $(0.00381)$ & $(0.00901)$ & $(0.00493)$ & $(0.00481)$ \\
& $0.0916^{* *}$ & $0.112^{* * *}$ & $0.0644^{*}$ & $0.229^{* * *}$ & 0.0293 & $0.131^{* * *}$ \\
assetdebt & $(0.0381)$ & $(0.0417)$ & $(0.0332)$ & $(0.0611)$ & $(0.0438)$ & $(0.0382)$ \\
& $0.181^{* * *}$ & 0.0263 & $0.0858^{*}$ & -0.0131 & 0.0548 & $0.163^{* * *}$ \\
growth & $(0.0476)$ & $(0.0580)$ & $(0.0485)$ & $(0.122)$ & $(0.0659)$ & $(0.0423)$ \\
& $-0.155^{* * *}$ & -0.0226 & $-0.100^{* *}$ & 0.0312 & -0.0992 & $-0.133^{* * *}$ \\
roa & $(0.0424)$ & $(0.0552)$ & $(0.0437)$ & $(0.121)$ & $(0.0631)$ & $(0.0323)$ \\
& $0.00109^{* * *}$ & $0.00126^{* * *}$ & $0.00136^{* * *}$ & $0.00160^{* * *}$ & $0.00151^{* * *}$ & $0.00103^{* * *}$ \\
occupy & $(0.00022)$ & $(0.000391)$ & $(0.00021)$ & $(0.00053)$ & $(0.000258)$ & $(0.000284)$ \\
& $-0.289^{* * *}$ & $-0.657^{* * *}$ & $-0.347^{* * *}$ & -0.266 & $-0.396^{* * *}$ & $-0.293^{* *}$ \\
managefee & $(0.100)$ & $(0.157)$ & $(0.0986)$ & $(0.179)$ & $(0.128)$ & $(0.121)$ \\
& $-0.350^{* * *}$ & $-0.657^{* * *}$ & $-0.368^{* * *}$ & $-1.102^{* * *}$ & $-0.624^{* * *}$ & $-0.264^{* *}$ \\
gdp & $(0.114)$ & $(0.135)$ & $(0.0960)$ & $(0.240)$ & $(0.144)$ & $(0.114)$ \\
& 0.0566 & $0.164^{* * *}$ & 0.0498 & 0.119 & $0.136^{* *}$ & -0.0169 \\
cons & $(0.0579)$ & $(0.0599)$ & $(0.0559)$ & $(0.0738)$ & $(0.0529)$ & $(0.0636)$ \\
& $0.114^{* * *}$ & $0.117^{* * *}$ & $0.132^{* * *}$ & $0.127^{* * *}$ & $0.163^{* * *}$ & $0.102^{* * *}$ \\
year & $(0.0189)$ & $(0.0256)$ & $(0.0170)$ & $(0.0344)$ & $(0.0239)$ & $(0.0206)$ \\
ind & control & control & control & control & control & control \\
adj. $R^{2}$ & control & control & control & control & control & control \\
$N$ & 0.069 & 0.079 & 0.067 & 0.159 & 0.112 & 0.050 \\
\hline \multirow{2}{*}{$N$} & 3498 & 1677 & 4365 & 685 & 2618 & 2557 \\
\hline
\end{tabular}

Table 4. Results.

\begin{tabular}{|c|c|c|c|c|c|c|}
\hline & \multicolumn{2}{|c|}{ Investment Expenditure } & \multicolumn{2}{|c|}{ Provincial officials change } & \multicolumn{2}{|c|}{ Exclusion of municipality } \\
\hline & invest 2 & invest 2 & invest 1 & invest 1 & invest 1 & invest 1 \\
\hline \multirow[t]{2}{*}{ shuji } & $0.00691^{\star *}$ & & $0.00927^{\star *}$ & & $0.00559^{*}$ & \\
\hline & $(0.00306)$ & & $(0.00438)$ & & $(0.00361)$ & \\
\hline \multirow[t]{2}{*}{ shizhang } & & -0.000616 & & -0.00103 & & -0.00160 \\
\hline & & $(0.00273)$ & & $(0.00338)$ & & $(0.00337)$ \\
\hline \multirow[t]{2}{*}{ cash } & $0.0925^{* * *}$ & $0.0930^{\star * *}$ & $0.0896^{* * *}$ & $0.0898^{\star * *}$ & $0.0536^{*}$ & $0.0538^{\star}$ \\
\hline & $(0.0280)$ & $(0.0280)$ & $(0.0292)$ & $(0.0291)$ & $(0.0313)$ & $(0.0313)$ \\
\hline \multirow[t]{2}{*}{ assetdebt } & $0.199^{* * *}$ & $0.198^{\star * *}$ & $0.0932^{\star *}$ & $0.0917^{\star *}$ & 0.0861 & 0.0859 \\
\hline & $(0.0290)$ & $(0.0289)$ & $(0.0454)$ & $(0.0454)$ & $(0.0570)$ & $(0.0570)$ \\
\hline \multirow[t]{2}{*}{ growth } & $-0.203^{\star \star \star}$ & $-0.202^{\star \star \star}$ & $-0.0988^{* *}$ & $-0.0975^{\star *}$ & -0.0796 & -0.0796 \\
\hline & $(0.0261)$ & $(0.0260)$ & $(0.0417)$ & $(0.0417)$ & $(0.0526)$ & $(0.0526)$ \\
\hline \multirow[t]{2}{*}{ roa } & $0.00108^{\star * *}$ & $0.00107^{* * *}$ & $0.00130^{* * *}$ & $0.00130^{* * *}$ & $0.00141^{* * *}$ & $0.00140^{* * *}$ \\
\hline & $(0.00017)$ & $(0.00017)$ & $(0.00019)$ & $(0.00019)$ & $(0.00021)$ & $(0.00021)$ \\
\hline \multirow[t]{2}{*}{ occupy } & $-0.409^{* * *}$ & $-0.411^{* * *}$ & $-0.344^{* * *}$ & $-0.347^{* * *}$ & $-0.381^{* * *}$ & $-0.382^{* * *}$ \\
\hline & $(0.0791)$ & $(0.0791)$ & $(0.0862)$ & $(0.0862)$ & $(0.0949)$ & $(0.0948)$ \\
\hline \multirow[t]{2}{*}{ managefee } & $-0.379^{* * *}$ & $-0.379^{* * *}$ & $-0.429^{\star * *}$ & $-0.430^{* * *}$ & $-0.446^{* * *}$ & $-0.445^{* * *}$ \\
\hline & $(0.0883)$ & $(0.0882)$ & $(0.0907)$ & $(0.0908)$ & $(0.107)$ & $(0.107)$ \\
\hline \multirow[t]{2}{*}{ gdp } & $0.0707^{\star}$ & $0.0698^{\star}$ & $0.0815^{\star}$ & $0.0890^{* *}$ & 0.0471 & 0.0425 \\
\hline & $(0.0402)$ & $(0.0403)$ & $(0.0423)$ & $(0.0421)$ & $(0.0441)$ & $(0.0441)$ \\
\hline \multirow[t]{2}{*}{ _cons } & $0.121^{\star * *}$ & $0.130^{\star * *}$ & $0.130^{\star * *}$ & $0.134^{\star * \star}$ & $0.130^{\star * *}$ & $0.139^{\star * *}$ \\
\hline & $(0.0137)$ & $(0.0136)$ & $(0.0146)$ & $(0.0148)$ & $(0.0172)$ & $(0.0174)$ \\
\hline year & control & control & control & control & control & control \\
\hline ind & control & control & control & control & control & control \\
\hline adj. $R^{2}$ & 0.094 & 0.094 & 0.071 & 0.071 & 0.069 & 0.068 \\
\hline$N$ & 5175 & 5175 & 5175 & 5175 & 4039 & 4039 \\
\hline
\end{tabular}


company types. Finally, this paper uses robustness tests to prove our research conclusion. The basic conclusions are as follows: Only party secretary changes will lead investment of listed companies significantly increase next year; the impact of changes in the mayor is not significant.

\section{References}

[1] Xu, C. (2011) The Fundamental Institution of China's Reforms and Development. Journal of Economic Literature, 49, 1076-1151.

[2] Amsden, A. (1989) Asia's New Giant: South Korea and Late Industrialization. Oxford University Press, Oxford.

[3] Wade, R. (1990) Governing the Market: Economic Theory and the Role of the Government in East Asia Industrialization. Princeton University Press, Princeton.

[4] Frye, T. and Andrei, S. (1997) The Invisible Hand and the Grabbing Hand. American Economic Review, 87, 354-358.

[5] World Bank (1993) The East Asia Miracle: Economic Growth and Public Policy. Oxford University Press, New York.

[6] Qian, Y. and Weingast, B.R. (1997) Federalism as a Commitment to Market Incentives. Journal of Economic Perspectives, 11, 83-92. https://doi.org/10.1257/jep.11.4.83

[7] Jones, B. and Olken, B. (2005) Do Leaders Matter? National Leadership and Growth since World War 2. Quarterly Journal of Economics, 120, 835-864.

https://doi.org/10.1093/qje/120.3.835

[8] Bernanke, B. (1983) Irreversibility, Uncertainty and Cyclical Investment. The Quarterly Journal of Economics, 98, 85-106. https://doi.org/10.2307/1885568

[9] Bloom, N., Floetotto, M. and Jaimovich, N. (2008) Really Uncertain Business Cycles. Working Paper, Stanford University, Stanford.

[10] Julio, B. and Yook, Y. (2012) Political Uncertainty and Corporate Investment Cycles. The Journal of Finance, 67, 45-84. https://doi.org/10.1111/j.1540-6261.2011.01707.x

[11] Yonce, A.T. (2010) Uncertain Growth Cycles, Corporate Investment and Dynamic Hedging. Dissertation of University of California, Berkeley.

[12] Cohen, L., Coval, J. and Malloy, C. (2011) Do Powerful Politicians Cause Corporate Downsizing? Journal of Political Economy, 119, 1015-1060. https://doi.org/10.1086/664820

[13] Pastor, L. and Veronesi, P. (2012) Uncertainty about Government Policy and Stock Prices. Journal of Finance, 67, 1219-1264.

https://doi.org/10.1111/j.1540-6261.2012.01746.x 
Submit or recommend next manuscript to SCIRP and we will provide best service for you:

Accepting pre-submission inquiries through Email, Facebook, LinkedIn, Twitter, etc. A wide selection of journals (inclusive of 9 subjects, more than 200 journals)

Providing 24-hour high-quality service

User-friendly online submission system

Fair and swift peer-review system

Efficient typesetting and proofreading procedure

Display of the result of downloads and visits, as well as the number of cited articles Maximum dissemination of your research work

Submit your manuscript at: http://papersubmission.scirp.org/

Or contact ojbm@scirp.org 